\title{
Поведение пользователей социальных сетей в условиях законодательной напряженности
}

\author{
Мария Крашенинникова
}

\begin{abstract}
В статье рассматриваются результаты проведенного разведывательного исследования, реализованного с помощью опроса среди разновозрастной аудитории социальных сетей Facebook, «ВКонтакте»

и «Одноклассники» на предмет изменения

их поведения в Интернете в условиях законодательной напряженности. Актуальность и новизна исследования подтверждаются формированием проблемного поля между активными пользователями соцсетей и правоохранительными органами в последние несколько лет. В ходе опроса рабочая гипотеза о том, что широкое освещение случаев преследования блогеров со стороны правоохранительных органов оказывает влияние на публичное поведение пользователей в социальных сетях, подтвердилась.

Ключевые слова: опрос, социальные сети, законодательство, пользователи, поведение.
\end{abstract}

@ Крашенинникова Мария Алексеевна кандидат филологических наук, старший преподаватель кафедры новых медиа и теории коммуникации факультета журналистики МГУ имени М.В. Ломоносова (г. Москва, Россия), mashagarnova@gmail.com

\section{Введение}

Социальные сети стали прочно входить в жизнь российских пользователей во второй половине 2000 гг.: "Одноклассники» (аналог американского портала classmates.com) и «ВКонтакте» были запущены в 2006 г., а в 2008 г. появилась русская версия Facebook. Следует отметить также весьма популярное приложение для публикации мобильных фотографий Instagram ${ }^{1}$ (с 2010 г.). С тех пор аудитория российского сегмента социальных сетей набирала обороты. На сегодняшний день количество пользователей социальных сетей в России следующее: «ВКонтакте» - 38,1 млн человек, Instagram - 29,6 млн, «Одноклассники» 23,8 млн, Facebook - 22,3 млн².

Соцсети становятся не только объектом массовой интернет-культуры, особенно в среде молодых людей, но и предметом детального изучения академическим и профессиональным сообществом. Основная масса литературы по социальным сетям представляет собой практические руководства по популяризации личного аккаунта пользователя или страницы его компании, коммерциализации своего присутствия в Сети (напр., см.: Румянцев, 2018; Сенаторов, 2017; Щербаков, 2019 и др.). Труды отечественных ученых широко представлены исследованием социальных сетей 
как объекта массовой культуры (Шипицин, 2011), модели формирования новых коммуникационных практик (Шахмартова, Болтага, 2011), трансформации визуальных образов (Ушкин, 2012), феномена информационного общества (Селезнев, Скрипак, 2013).

Изучением поведения пользователей в социальных сетях интересуются психологи и социологи. В частности, эта тема нашла свое отражение в трудах о формировании черт личности и активности пользователей в социальной сети «ВКонтакте» (Щебетенко, 2013), об отрицательном влиянии социальных сетей на психологию личности (Милова, 2012), о моделях влияния (Губанов, Новиков, Чхартишвили, 2009), психологических предикторах (Сигов, Баранюк, Нечаев, Крылова, 2018). Политический аспект в поведении пользователей в социальных сетях отражен в публикации результатов всероссийского социологического исследования о политической субъектности пользователей соцсетей (Бродовская, Домбровская, Синяков, 2015).

Юридические аспекты, касающиеся пробелов в текущем российском законодательстве, затронуты в публикациях об оскорблении чувств верующих (Федотова, 2016), разграничении массовых беспорядков с экстремизмом (Якунин, 2012), о социальных сетях как инструменте распространения экстремизма (Рудик, Волков, 2017), проблемах совершенствования правовой базы (Кубякин, 2010). Изучением социальных сетей активно занимаются не только медиаисследователи, но и социологи, экономисты, политологи, лингвисты, представители IT-сферы.

По мнению автора, необходимо также отметить, что количество имеющихся академических научных публикаций и исследований по социальным сетям в сопряжении с законодательным аспектом является недостаточным. В связи с этим считаем важным мониторинг исследователями возникшего проблемного поля между пользователями социальных сетей и правоохранителями, присутствие научного сообщества в изучении данной темы.

Социальные сети по мере своего распространения в пользовательской среде фактически заменили собой блогосферу пользователи стали активно создавать UGCконтент для публикации именно в социальных сетях. При этом тематика публикуемого контента весьма разнообразна - от информации личного характера до политических дискуссий, всевозможной критики и текстов с компрометирующим содержанием.

В последние годы в российских СМИ все чаще стали появляться публикации о возбуждении уголовных и административных дел против пользователей популярных социальных сетей за распространение экстремизма, разжигание межнациональной розни, оскорбление религиозных чувств, неуважении к власти и пр. ${ }^{4}$ Широкое распространение подобного рода информации, непросвещенность большинства населения в юридических аспектах, а также непрозрачность законодательства порождают напряженность среди активных пользователей Сети. Настоящее исследование посвящено изменению поведения пользователей в социальных сетях в связи с участившимися случаями преследования граждан за онлайн-публикации. В качестве первичной апробации некоторые результаты проведенного опроса были кратко представлены в виде доклада на международном научном форуме «Медиа в современном мире. 58-е Петербургские чтения» (СПбГУ, Высшая школа журналистики и массовых коммуникаций, Россия, 18-19 апреля 2019).

\section{Законодательная напряженность}

В 2010 гг. в России было отредактировано и дополнено несколько законов, напрямую влияющих на публичные высказывания граждан 5 . В первую очередь это 
коснулось тех, кто активно выражает свои позиции на открытых интернет-площадках, в частности в виде постов/репостов в социальных сетях. Стоит отметить, что в поле зрения правоохранительных органов попадают не только оригинальные посты-высказывания пользователей Сети, но и репосты - случаи, когда один человек делится записью другого, добавляя от себя комментарий-сопровождение или же обходясь без него. Репост чужого текста для законодателей считается таким же постом, как и оригинальный ${ }^{6}$. В фокусе внимания правоохранителей и общества оказались посты, содержание которых можно квалифицировать как распространение экстремизма, разжигание межнациональной розни, оскорбление религиозных чувств, неуважении к власти и пр.

Зачастую проблема применения данных законов к интернет-пользователям и правильное понимание последними своих прав и обязанностей состоит в недостаточном разъяснении сути внесенных изменений со стороны законодателей. В частности, пользователям не всегда понятно, что конкретно может считаться оскорблением, а что допустимой критикой, где проходит грань между правом выражения собственного мнения и неуважением к группе лиц или политическому устройству государства, как свободно высказываться в Сети и при этом не нарушать текущее законодательство, на что обращать внимание при репостах чужих текстов и пр. В свою очередь, подробные и детальные разъяснения требуются и представителям правоохранительных органов на местах для более корректной трактовки применяемых ими в отношении граждан законов. Автор настоящего исследования полагает, что именно непрозрачность, отсутствие четких критериев и трактовок в отечественном законодательстве способствует возникновению проблемного поля между правоохранительной системой и активными пользователями социальных сетей. Подобная практика, на наш взгляд, порождает напряженность среди активных пользователей социальных сетей и может негативно отражаться на их желании открыто выражать свое мнение на разные темы (исходя из данного тезиса сформулирована рабочая гипотеза настоящего исследования).

Онлайн-ресурсы широко освещают тему применения законодательных практик к пользователям социальных сетей и блогерам. В частности, общественная организация «РосКомСвобода» приводит статистику уголовного преследования граждан за публикации в соцсетях с 2015 г. Согласно их данным, в 2015 г. таких дел было 187, в 2016 г. - 184, в 2017 г. - 218, в 2018 г. 227, а в 2019 г. (по данным на 27.08.2019) 78. При этом подавляющее большинство перечисленных дел (суммарно 511 за период 2015-2019 гг.) было возбуждено против пользователей отечественной социальной сети «ВКонтакте». Чаще всего обвинения касались призыва к экстремизму и/или демонстрации экстремистской символики.

\section{Опрос пользователей социальных сетей}

Осенью 2018 г. методом рандомной выборки был проведен пилотный опрос среди пользователей популярных социальных сетей Facebook, «ВКонтакте» и «Одноклассники» с целью выяснить, изменилось ли поведение респондентов в связи с регулярными сообщениями в СМИ об уголовном преследовании блогеров. В опросе анонимно приняли участие 117 человек из крупных городов России (Москва, СанктПетербург и др.), возраст респондентов варьировался от 16 до 58 лет. Уровень образования опрошенных разнообразен законченное высшее (бакалавр, магистр, специалист) - 38\%, незаконченное высшее (студент) - 45\%, ученая степень - 15\%, среднее специальное - 2\%. 
Рабочей гипотезой опроса стало предположение о том, что широкое освещение случаев преследования блогеров со стороны правоохранительных органов оказывает влияние на публичное поведение пользователей в социальных сетях. Респондентам было задано десять вопросов, среди которых были как вопросы демографического характера, так и по существу исследования. Большинство опрошенных указали, что зарегистрированы в социальных сетях «ВКонтакте» и Facebook (109 и 106 соответственно), треть респондентов (36) - в "Одноклассниках», наибольшее количество постов делают в «ВКонтакте» (73), далее следуют Facebook (54) и «Одноклассники» (2).

Респонденты в основном знают о том, что государство отслеживает различные записи пользователей в социальных сетях. Подавляющее большинство опрошенных (82\%) слышали из СМИ о конкретных случаях, когда чьи-то посты в социальных сетях признавались нарушающими законодательство. Несколько человек (7\%) ответили, что подобная ситуация коснулась знакомых им людей. Лишь малая доля опрошенных (11\%) заявили, что не имеют представления о случаях нарушения закона в социальных сетях.

При этом в ответе на вопрос: «Как вы оцениваете повышенное внимание правоохранительных органов к поведению пользователей в социальных сетях?» мнения респондентов разделились: $47 \%$ ответили - «отрицательно», 43\% считают, что вопрос слишком сложный и надо детально разбираться в каждом конкретном случае, 6\% отметили, что относятся положительно к повышенному вниманию правоохранителей к социальным сетям, 4\% пока не определились со своей позицией.

На один из ключевых вопросов исследования, изменилось ли собственное поведение пользователей в социальных сетях в связи с активным вниманием правоохранителей к высказываниям граждан в Интернете (можно было выбрать более одного варианта ответа), большинство респондентов (51\%) ответили отрицательно, так как никогда не высказывались публично на «острые» темы. При этом более четверти опрошенных (31\%) стали гораздо внимательнее к своим постам. Чуть менее четверти респондентов (27\%) заявили, что стали критичнее относиться к тому, что «лайкают» в социальных сетях. 21\% сказали, что стали писать более сдержанные комментарии в Сети. 15\% опрошенных перестали затрагивать в своих постах «острые» темы. И только 14\% респондентов ответили, что продолжают писать обо всем и принципиально не меняют ничего в своем поведении в социальных сетях. 23\% опрошенных признались, что имеют довольно низкую активность на упомянутых популярных ресурсах.

Последний вопрос, заданный респондентам в рамках проводимого исследования, касался их прогнозов развития ситуации. Подавляющее большинство участвовавших в опросе (77\%) считает, что пользователи будут стремиться создавать как можно больше приватности вокруг своих аккаунтов - писать под псевдонимами, использовать ненастоящие фото в профиле, ограничивать круг читателей своих записей и пр. Однако стоит отметить, что данный прогноз фактически вступает в противоречие с периодически озвучиваемыми инициативами некоторых законодателей о регистрации в Сети по действующему гражданскому паспорту. При этом личные наблюдения автора статьи за молодежной аудиторией «ВКонтакте» показывают, что у пользователей студенческого возраста действительно нередко встречаются деперсонализированные аккаунты. Люди станут осторожнее высказываться в соцсетях так считает 27\% опрошенных. Остальные предполагают, что вряд ли что-то изменится (19\%) и, вероятно, люди станут проводить меньше времени в социальных сетях (6\%). 
При этом 12 респондентов также дали свой развернутый ответ на поставленный вопрос. В основном пользователи негативно оценили текущую ситуацию, некоторые из них предположили, что дальше «придется больше шифроваться и завуалированно обсуждать некоторые темы», «люди будут чаще встречаться вживую», «подростки никогда не станут осторожнее» и др.

\section{Заключение}

Напрашивается вывод о некоторых изменениях картины поведения пользователей в социальных сетях в связи с контролем гражданской сетевой активности со стороны правоохранительных органов. Однако происходящие изменения пока нельзя назвать радикальными, так как большинство опрошенных считают, что их посты в соцсетях не носят «острый» характер. При этом любопытен тот факт, что более четверти респондентов все же стали внимательнее относиться к своим действиям в Сети. Данные настоящего опроса подтверждаются и личными наблюдениями автора статьи за поведением пользователей в социальных сетях Facebook и «ВКонтакте».

Сомнения пользователей социальных сетей о законных возможностях своего публичного высказывания исходят, на наш взгляд, из непрозрачности соответствующего текущего законодательства, а также отсутствия конкретных и понятных разъяснений относительно трактовки опорных понятий. Данная ситуация способствует «стерильности» Интернета, потери «живого мнения», напряженности пользователей. Однако, мы считаем, что детальные, обоснованные и доступно изложенные толкования текущего законодательства для интернетпользователей и правоохранителей, медиаобразование в школах, практика предупредительных разъяснений позволили бы избежать существующего проблемного поля, снять психологическую напряженность между блогерами и законодателями, повысить ответственность граждан за публичные высказывания в Сети.

Проведенный опрос выявил наличие зависимости между поведением пользователей в социальных сетях и активностью государства по выявлению случаев нарушения законодательства в Интернете. Таким образом, выдвинутая нами в начале исследования гипотеза о том, что широкое освещение случаев преследования блогеров со стороны правоохранительных органов оказывает влияние на публичное поведение пользователей в социальных сетях, подтвердилась.

\section{Примечания}

${ }^{1}$ Социальная сеть Instagram не представлена в проведенном автором опросе, т.к. преимущественно направлена на публикацию визуального контента, а настоящее исследование посвящено в основном текстовым публичным высказываниям пользователей.

2 Курносова Е. Социальные сети в цифрах / Mediascope. Режим доступа: https: mediascope.net/upload/iblock/f97/18.04.2019_Mediascope_Екатерина\%20Курносова_РИФ+КИБ\%202019.pdf.

3 Летом 2019 г. общественная организация «РосКомСвобода» опубликовала мониторинг преследования граждан за онлайн-публикации: Что делать, если Вас привлекают за репост? // Мониторинг преследования граждан за онлайн-публикации. Режим доступа: https://blackscreen.report/ (дата обращения: 26.08.2019). 
4 Речь идет в основном о следующих документах: «Нарушение права на свободу совести и вероисповеданий» (ст. 148 УК РФ, в ред. 2013 г.); “О противодействии экстремистской деятельности» (№114-Ф3 от 25.07.2002, с изм. и доп. от 02.12.2019, в ред. 31.07.2020); «О внесении изменений в Кодекс Российской Федерации об административных правонарушениях" (№28-Ф3 от 18.03.2019) и «О внесении изменений в Федеральный закон “Об информации, информационных технологиях и о защите информации"» (№30-ФЗ от 18.03.2019); “О внесении изменений в статью 15.3 Федерального закона “Об информации, информационных технологиях и о защите информации»"» (№31-ФЗ от 18.03.2019); “Возбуждение ненависти либо вражды, а равно унижение человеческого достоинства» (ст. 282 УК РФ в ред. 2018 г.).

5 Запрещенный репост: за что в Интернете можно получить штраф и срок. Режим доступа: https://www.rbc.ru/technology_and_media/21/10/2014/544510e6cbb20f 482aecf5c5 (дата обращения: 27.08.2019).

6 Мониторинг преследования граждан за онлайн-публикации. Режим доступа: https://blackscreen.report/diagram/ (дата обращения 27.08.2019).

7 Например, в 2017 г. депутат В. Милонов внес в Госдуму законопроект, согласно которому при регистрации в соцсетях необходимо предоставлять паспортные данные. Режим доступа: https://www.ntv.ru/novosti/1794220/ (дата обращения: 28.08.2019).

\section{Библиография}

Бродовская Е.В., Домбровская А.Ю., Синяков А.В. Политическая субъектность пользователей социальных сетей в России: результаты всероссийского социологического исследования // Вестн. Моск. гуманит. ун-та им. М.А. Шолохова. Сер.: История. Политология. 2015. № 2. С. $80-87$.

Губанов Д.А., Новиков Д.А., Чхартишвили А.Г. Модели влияния в социальных сетях // Управление большими системами: сб. трудов. 2009. Вып. 27. С. 205- 274.

Кубякин Е.О. Проблемы совершенствования правовой базы противодействия молодежному экстремизму в России // Теория и практика общественного развития. 2010. Вып. 2. С. 238- 243.

Милова Е.А. Влияние социальных сетей на психологию личности // Интерэкспо ГеоСибирь. 2012. Т. 1. № 6. С. 81-83.

Рудик М.В., Волков Д.В. Социальные сети как средство распространения экстремизма // Вестн. Краснодарск. ун-та МВД России. 2017. № 2 (36). С. 32- 35.

Румянцев Д. Продвижение бизнеса «ВКонтакте». Системный подход. СПб.: Питер, 2018.

Селезнев Р.С., Скрипак Е.И. Социальные сети как феномен информационного общества и специфика социальных связей в их среде // Вестн. Кемеровск. гос. ун-та. 2013. № 2 (54). T. 3. С. 125-131.

Сенаторов А.А. Битва за подписчика «ВКонтакте»: SMM-руководство. М.: Альпина Паблишер, 2017.

Сигов А.С., Баранюк В.В., Нечаев В.В., Крылова О.С. Психологические предикторы поведения пользователей в социальных сетях: определение, анализ, описание, использование // Современные информационные технологии и ИТ-образование. 2018. T. 14. № 3. C. 663- 671. 
Ушкин С.Г. Визуальные образы пользователей социальной сети «ВКонтакте» // Мониторинг общественного мнения: экономические и социальные перемены. 2012. № 5 (111). C. 159-169.

Федотова Ю.Е. Оскорбление религиозных чувств верующих и уголовный закон: работа над ошибками // Юридическая наука и правоохранительная практика. 2016. № 1 (35). С.199- 205.

Шахмартова О.М., Болтага Е.Ю. Психологические аспекты общения в социальных сетях виртуальной реальности // Изв. ПГПУ им. В.Г. Белинского. 2011. № 24. С. 1002-1008.

Шипицин А.И. Феномен социальных сетей в современной культуре // Изв. Волгоградск. гос. пед. ун-та. 2011. № 3 (57). С. 36-40.

Щебетенко С.А. Большая пятерка черт личности и активность пользователей в социальной сети «ВКонтакте» // Вестн. Южно-Уральск. гос. ун-та. 2013. № 4. Т. 6. С. 73- 83.

Щербаков С. Партизанский маркетинг в социальных сетях. Инструкция по эксплуатации SМM-менеджера. СПб.: Питер, 2019.

Якунин А.И. Спорные вопросы разграничения массовых беспорядков с экстремизмом // Юридическая наука и практика: Вестн. Нижегородск. акад. МВД России. 2012. № 20. C. 131- 134. 